\title{
The Evidence of the Fiscal Incentive to Increase the HDI: The Case of Maranhão
}

\author{
Fernando Silva Lima ${ }^{1} \&$ Mariano Yoshitake ${ }^{2}$ \\ ${ }^{1}$ Federal Institute of Education, Science and Technology of Maranhão-Bacabal Campus, Avenida Governador João \\ Alberto, CEP: 65.700-000, Areal Neighborhood, Bacabal-MA-Brazil \\ ${ }^{2}$ Ceuma University, Teaching Association. Josué Montello Street, n.01, Renascença Garden. 65075120-São Luís, \\ MA-Brazil \\ Correspondence: Fernando Silva Lima, Federal Institute of Education, Science and Technology of \\ Maranhão-Bacabal Campus, Avenida Governador João Alberto, CEP 65.700-000, Areal Neighborhood, \\ Bacabal-MA-Brazil.
}

Received: April 26, 2018

Accepted: July 19, 2018

Online Published: July 25, 2018

doi:10.5430/ijba.v9n4p214

URL: https://doi.org/10.5430/ijba.v9n4p214

\begin{abstract}
This article is the result of an investigation about tax incentives in the State of Maranhão, where the purpose was to answer the question: what is the efficiency of tax incentives in relation to the impact on the state of employment? The hypothesis behind this research is that the idea of the Maranese government to create fiscal incentives to stimulate the generation of employment and income can not impact the regions with low human development index (HDI). The general objective of this article is to verify the relationship between the fiscal incentive and the balance of jobs between 2010 and 2016 in Maranhão in regions with lower HDI. The specific objectives are: to investigate the policy of granting the fiscal incentive "more companies" in Maranhão; compare the number of jobs generated with the number of companies that benefited from the tax incentive; to verify the evolution of the jobs generated in each mesoregion and to know the economic activities that generate more jobs in the state. This study is justified because it believes in the relevance it can bring to the academic environment and to the society that encompasses government, companies and professionals, since it presents a more comprehensive perspective regarding economic development in the local regional government of Maranhão. It considers the methodology of this study, a field research, but of quantitative-descriptive character. Among the results, it was identified that the fiscal incentive had no impact on job creation in the Meso-regions that have the lowest HDI indices in the state of Maranhão between 2010 and 2016.
\end{abstract}

Keywords: fiscal incentive, government policies, social indicators, Maranhão, Northeast Brazil

\section{Introduction}

Noting that the Government of Maranhão, through Law No. 10259 of June 16, 2015, created the "more companies" program in which it aims to diversify the industrial matrix, form industrial densities in the economic regions and integrate productive chains essential to the development and generation of employment and income in the State.

It is observed that the greatest attraction in this Law is the reduction of up to $95 \%$ (ninety-five percent) of the value of the tax on operations related to the movement of goods and on services of interstate, intermunicipal and communication services (ICMS) for companies that are deployed in the 30 (thirty) municipalities with the lowest HDI, as well as companies that settle in municipalities that belong to the Integrated Development Network (RIDE), that is, cities located in regions metropolitan.

Considering Law No. 13,089, dated January 12, 2015, which provides the list of municipalities that integrate Ride, it is noted that the city of Timon is the only municipality of the contemplated by the program "more companies".

Therefore, there is a conception that companies are moving to metropolitan areas to establish themselves in municipalities with a low HDI where it does not provide basic sanitation, health, safety and labor infrastructure, and in this case, it is the reduction of $95 \%$ of ICMS ends up encouraging companies to settle in the municipality of Timon, instead reaching the poorest cities. 
According to Carvalho (2015, page 86) the new period demonstrates that it is no longer possible for the frontiers of accumulation to be opened only by investments concentrated in large projects, and intense cooperation is required between the various spheres of power to create fields of attraction for productive investment, guaranteeing from the works of infrastructure to the training and qualification of the workforce.

In this context, it can be said that tax incentive is not always a viable alternative to stimulate the development of a region, since Reese (2005 apud Wassmer and Anderson, 2001) affirms that they provide little benefit to local economies, rich or poor

Reese (2005) argues that in the last two years, the Brazilian government has increased its fiscal incentives, according to Law 10259/2015, to stimulate the implantation and expansion of companies in the state. decades, academics and evaluators have made a number of recommendations to reformulate local economic development policies. At any time, he recommended the use of tax reduction.

In some cases, the reduction of taxes comes through fiscal incentives and is evidently what the Maranese government has done in the 21 st century, which is to grant tax incentives. It should be noted that this may not be a suitable policy for a government seeking to develop a place or a region.

Initially, studying and planning is the most coherent method for any ruler that seeks to create economic development policies, since the basic infrastructure issues of each municipality should be taken into account, among them, the capacity of labor that these venues can offer.

It is noticed that the government of Maranhão has been passing an image that the fiscal incentives is a strong support policy to stimulate economic growth and thus, improve the life of the citizen of Maranhão, however, where tax incentives are concentrated has not worked, because some municipalities grew economically, but there was not in the same proportion, progress in quality of life (OTTATI, 2013).

It is worth mentioning that in Maranhão there have always been incentive policies, but some regions remain poor and the MHDI (Note 1) in some municipalities is one of the worst in Brazil. Fiscal incentives are hardly created with the intention of stimulating poor regions, since in the planning of this incentive, it brings together the production and distribution of goods and the expansion and utilization of human capacities (OLIVEIRA 2014, page 42, UNDP, 2010).

Therefore, it is considered that before creating tax incentives for any region or municipalities including the most deprived, it is interesting to know the case of South Korea and Singapore in which they changed the productive structure of the economy using technology and standardization (FELIPE, KUMAR and ABDON, 2010), since it seems that fiscal incentives have lost the leverage capacity of the investment in the state (ARAÚJO, 2017, p. 18).

Thus, the problem question of this research is: what is the efficiency of fiscal incentives in relation to the impact on the balance of jobs in the Maranhão mesoregions? The guiding hypothesis of this research is that, although it does not meet in parts the regions with low economic development index, the fiscal incentives can benefit Maranhão by opening new jobs and, thus, to promote the economic development of the region.

The general objective of this article is to verify the relationship between the fiscal incentive and the balance of jobs between 2010 and 2016 in Maranhão in regions with lower HDI. The specific objectives are: to investigate the policy of granting the fiscal incentive "more companies" in Maranhão; compare the number of jobs generated with the number of companies that benefited from the tax incentive; to verify the evolution of the jobs generated in each mesoregion and to know the economic activities that generate more jobs in the state.

\section{The Fiscal Incentive of the State of Maranhão}

The state of Maranhão is one of the poorest in the northeastern region and in Brazil, therefore, it has great deficiencies and few social indicators that influence income and economic structure, aggravated by the poor supply of public services (CARVALHO, 2015, 24).

It is understood that low social indicators are related to the large number of people living in extreme poverty that correspond to $25.8 \%$ of the total of 1.7 million people (IBGE, 2010).

It is understood that in some cases, due to the low rate of job creation, the income of these people is equivalent to R $\$ 70$ in which they are guaranteed by the family scholarship program (Note 2) (BRASIL, MDS, 2014).

Thus, in 2010, the Government of Maranhão created the "Promaranhão (Note 3)" program, but in 2015 the state revoked it and created the "more companies (Note 4)", with the aim of diversifying the industrial matrix, forming industrial densities in the economic regions and integrating productive chains essential to the development and generation of jobs and income in the state. 
To ensure the diversification of the industry in the state, the government proposed a reduction of up to $95 \%$ (ninety-five percent) of the value of the tax on operations related to the movement of goods and on services of interstate, intermunicipal and communication services (ICMS ) for 15 years, but, according to Law No. 10,690 of September 26, 2017, the government extends to 20 years and inclusive, includes in this reduction percentage (95\%), Municipality of the Integrated Development Network (RIDE), or cities that belong to a metropolis;

It is understood that, if investors are entitled to such reduced ICMS (95\%) may prefer to settle in one of the 30 (thirty) municipalities of lower HDI, or in municipalities belonging to metropolitan regions.

In view of this, it is conceived that the benefit of reduction of ICMS may favor the metropolitan areas of Maranhão instead of other regions, including, investors may ignore municipalities with low HDI due to the lack of infrastructure in the areas of basic sanitation, health, safety and manpower.

A research carried out on tax incentives in the state of Tocantins by Rodrigues and Araújo (2016), it was emphasized that investing in infrastructure, logistics potential and seeking the industry for the state of preference those that use the local raw material and the qualification of the hand of can attract investors.

Therefore, it is a concept that, not always, the reduction of a tax is a viable alternative to stimulate the economic development of a region, since, Reese (2005) affirms that in the last two decades, academics and evaluators have made a series of recommendations to reformulate local economic development policies and at no time, recommended the use of tax reduction (Note 5).

In this sense, it can be seen that in Maranhão the reduction of taxes has come from fiscal incentives and that according to Ottati (2013), has not worked, therefore, some municipalities grew economically, but there was not in the same proportion, progress in the quality of people's lives.

It is understood that, in some cases, the quality of life of the individuals may be associated with a lack of job generation and income. Therefore, the guiding question of this article is: what are the impacts of the fiscal incentive in the generation of employment in the municipalities that possess the lowest HDI(Note 6) in Maranhão and Brazil?

In view of the above, this article has as general objective to verify if the fiscal incentive had impact on the generation of employment in the municipalities that have the lowest HDI indices of the state of Maranhão. Therefore, the study analyzes the development of employment generation during the concession of the fiscal incentive in Maranhão through the Meso-regions (Note 7) between 2010 and 2016.

\section{Research Methodology}

This article has as object of study the fiscal incentive policy in Maranhão. Due to the territorial extension of Maranhão, this study aimed to focus on mesoregions of the state, such as the center, east, west, north and south of Maranhão. Therefore, this study sought to analyze the regional development in the mesoregions, through fiscal incentives, between 2010 and 2016.

In order to identify the criteria established for granting the most recent tax incentive in the state, it was necessary to conduct a survey on the site of the State Treasury Secretariat (SEFAZ-MA) to identify and characterize the "more companies" program, the number of companies benefited by the incentive and number of municipalities with the lowest HDI in each mesoregion of the state and compare them. This preference consisted of the sample process for this study.

Then, a search was made on the site of the Ministry of Labor and Employment (MTE) on jobs generated and on economic activities in the state, but for that, a login and password was provided by the public agency and thus, it was possible to verify if the main economies evolved between 2010 and 2016 in each mesoregion.

When carrying out the procedure and collecting the information about the "more companies" program, on the companies benefited, on the numbers of municipalities with the worst HDI in each mesoregion, these were codified in the program Microsoft Excel and later transformed into Figure.

However, on the evolution of jobs generated by mesoregions and economic activities, it was necessary to use statistics (Note 8), but the Figures were analyzed based on Pearson's correlation coefficient.

Pearson's and Stanton's (2001, p. 1) correlation coefficient is a measure of bivariate association (strength) of the degree of relationship between two variables. For Moore (2007), correlation measures the direction and degree of the linear relationship between two quantitative variables (Moore, 2007, pp. 100 and 101).

According to Figueiredo Filho and Silva Júnior (2009, p. 118) the Pearson correlation coefficient (r) is a measure of linear association between variables. For Figueiredo Filho and Silva Júnior (2009, p. 118), the Pearson correlation case (r) is worth the latter parameter, that is, it is a measure of the shared variance between two variables. On the other hand, 
the linear model assumes that the increase or decrease of a unit in the variable X generates the same impact in Y. In graphical terms, by linear relation it is understood that the best way to illustrate the pattern of relationship between two variables is through a straight line. Therefore, the Pearson correlation (r) requires a sharing of variance and that this variation is linearly distributed (FIGUEIREDO FILHO AND SILVA JÚNIOR, 2009).

According to Figueiredo Filho and Silva Júnior (2009, p. 119), the Pearson correlation coefficient (r) varies from -1 to 1. In the Person correlation coefficient, the values can indicate positive or negative direction of the relationship and even show strength of the relationship between variables, so a correlation to make perfect (-1 or 1) must necessarily be exact, but also, if the value of a correlation is zero indicates that there is no linear relationship between the variables.

However, extreme values ( 0 or 1 ) are difficult to find in practice, it is important to discuss how researchers can interpret the magnitude of the coefficients (FIGUEIREDO FILHO \& SILVA JÚNIOR, 2009).

Therefore, Cohen (1988) says that values between 0.10 and 0.29 can be considered small; scores between 0.30 and 0.49 can be considered as mean; and values between 0.50 and 1 can be interpreted as large and for Dancey and Reidy (2005) they point to a slightly different classification: $r=0.10$ up to 0,30 (weak); $r=0.40$ to 0.6 (moderate); $r=0.70$ to 1 (strong).

Therefore, it is known that the closer to 1 the greater the degree of linear statistical dependence between the case variables, otherwise, the closer to zero, the lower the strength of this relation.

\section{Overall Summary of the Most Recent Tax Incentive of Maranhão Designed "More Companies"}

According to the exploratory research carried out on SEFAZ-MA's official website, table 01 presents a synthesis of the most recent program. This incentive was created through Law 10,259, dated June 16, 2015, which establishes the program for industrial development and economic integration of the State of Maranhão "Mais Empresas", originating from the program "promaranhão" (Law No. 9,121, March 4 of 2010). The difference between the "more companies" program and the old "promaranhão" program is to increase the benefit and reduction of the ICMS, as well as the extension of the period for the use of the incentive.

Table 1. About the "more companies" program in Maranhão

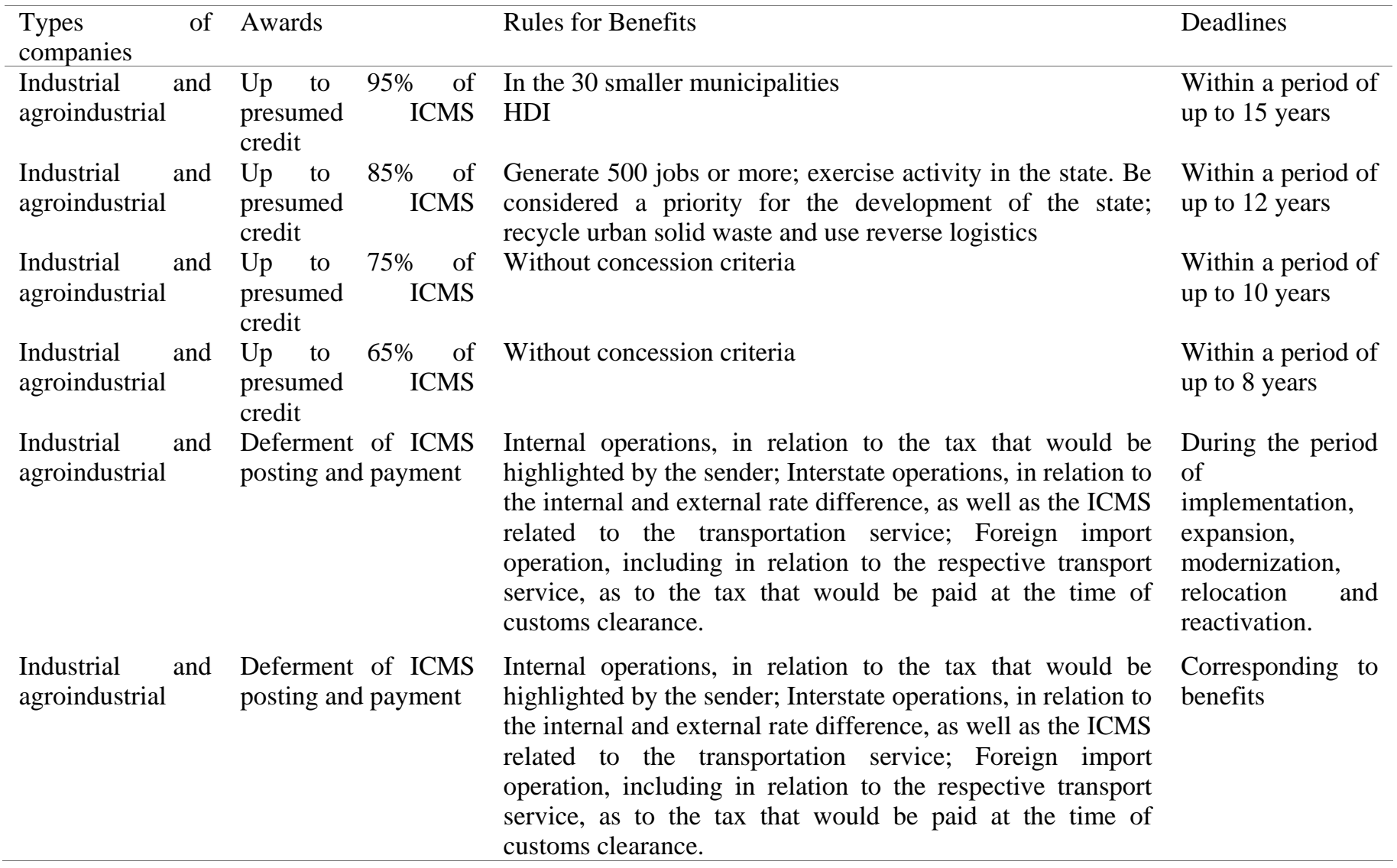

Source: Seinc (Note 9)-MA, 2017. (Data organized by the authors). 
In relation to the criteria established by the Maranhão Government for the concession of the "more companies" program, the following preliminaries were established: investment volume; number of jobs generated; have links with regional production chains; purchase of inputs in the local market; adoption of social and environmental responsibility measures; be installed or have influence in the municipalities with the lowest HDI in the state (MARANHÃO, SEINC, 2017).

To date, 53 companies have benefited from this program, including: 02 from Açailândia; 03 of Bacabeira; 02 of Balsas; 03 of Caxias; 02 of Codó; 01 of Davinópolis; 03 by Governor Edsison Lobão; 09 of Empress; 03 of Itapecuru Mirim; 01 of Miranda do Norte; 01 of Quarries; 01 by President Dultra; 01 of Fox; 01 of Santa Luzia do Parua; 17 of São Luís; 01 of Timon; 01 of Tuntum and 01 of Tutóia, therefore, all are active. It should be noted that 02 companies closed their activities in accordance with the cadastral status of the CNPJ in the Federal Revenue Portal of Brazil, in which 55 companies benefited in the "more companies" program (MARANHÃO, SEINC, 2017).

In addition, it was noted that almost 50\% of the companies benefited by the tax incentive "more companies", are concentrated in São Luís and Imperatriz. Another factor observed is that up to the present time, municipalities cited in the list of 30 municipalities with the lowest HDI in the state were not found companies encouraged in these cities.

\section{Analysis of the Influence of Tax Incentives in the Municipalities With the Highest HDI of Maranhão}

In view of the fact that fiscal incentives are concentrated in municipalities located near cities with low HDI, this study sought to analyze the data through the state mesoregions.

I. The number of beneficiaries versus the number of poor municipalities in Maranhão per meso-region

The first perception was about the center of Maranhão, where it is a region very affected by the lack of regional development, since the poorest municipalities of the federation are located in this region. See Figure 1.

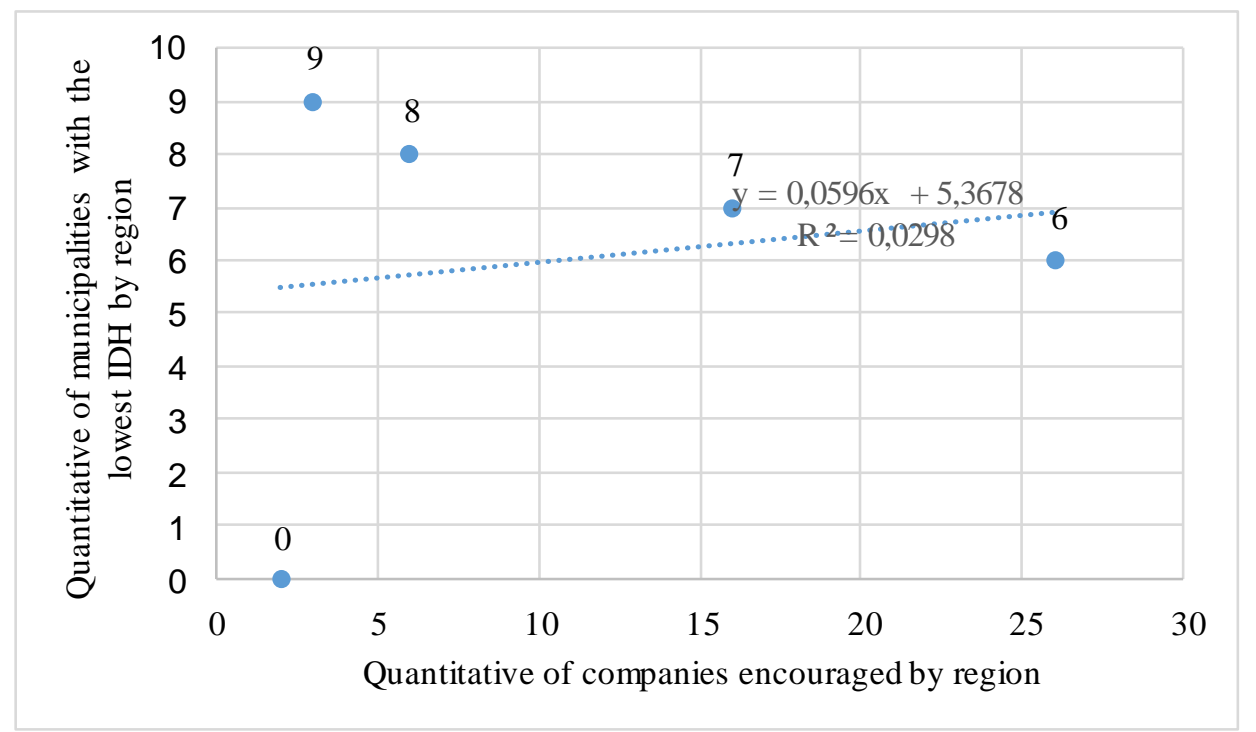

Figure 1. Municipalities with low HDI and companies encouraged in each mesoregion

Source: Seinc-MA e Sefaz-MA, 2017. (Data organized by the authors).

In relation to the dispersion chart 01 , which refers to the "more companies" program and the regions with the low HDI of Brazil according to the statistics, it can be said that there was no relation or approximation of impacts between variable $\mathrm{X}$, which is the quantitative of the municipalities with the lowest HDI by region and variable $\mathrm{Y}$, which is the quantitative index of firms encouraged by region, since, based on the linear coefficient of Person, $\mathrm{R}^{2}$ is 0.0298 .

Based on Dancey and Reidy (2005), it is understood that for this relationship to occur between the fiscal incentive and the regions, the result of (r) should be between 0.10 and 0.30 , which in this case would be considered weak; or 0.40 to 0.60 that would be considered moderate or between 0.70 to 1 that would be considered strong, but in none of these cases did this occur. 
Thus, some issues in Figure 1 were weighted by parts:

- It is observed that point 9 was far from the linear line, based on this, it is conceived that the municipalities with the worst HDI in which the central region of Maranhão belongs may not enjoy the benefits that the fiscal incentive granted to companies can bring to a locality, such as ICMS, which is passed on to municipalities and transformed into services rendered to society.

- According to the statistics, it is noted that point 8 is also far from the linear straight line based on this, it is noticed that although the eastern region of Maranhão is less distant from the line, in relation to the center of Maranhão, this locality also show little possibility of being fomented by the public policies of incentive, since the rules of concession allowed the companies to enjoy the tax advantage in an economically more developed region.

- It is noticed that the zero point was the farthest from the straight line, this must have occurred because when analyzing the region of the south of Maranhão it is noticed that there are no municipalities with the worst HDI of Brazil, but, this region was contemplated with the benefits of tax incentives because new incentive companies were established and, thus, generated new jobs, that is, they generated jobs and income in the region.

- $\quad$ Finally, it can be noted that the western and northern regions of Maranhão, according to the data, were the ones closest to the linear straight line, it is understood that this occurs because these regions have a large number of companies encouraged and few municipalities with low HDI and this may be associated with economic development, the great concentration of industry and trade in the region.

According to Lynn (1980), the fact that the State fosters fiscal incentive policies produces specific effects for the development of the local industrial complex in which, for Peters (1986), it can be through the promotion of economic growth or local development, incentives directly affect the lives of citizens.

It is worth noting that, on the one hand, there is the fiscal incentive of the government and, on the other hand, industrialization that creates a peak of opportunities that it is not able to maintain after the implementation phase, when this opportunity is greater than the demand of FURTADO, 2005). Therefore, fiscal incentive policies should be planned so as not to jeopardize the regional development strategy in the State.

II. Comparison of the evolution of jobs generated between the most incentivized and least incentivized regions

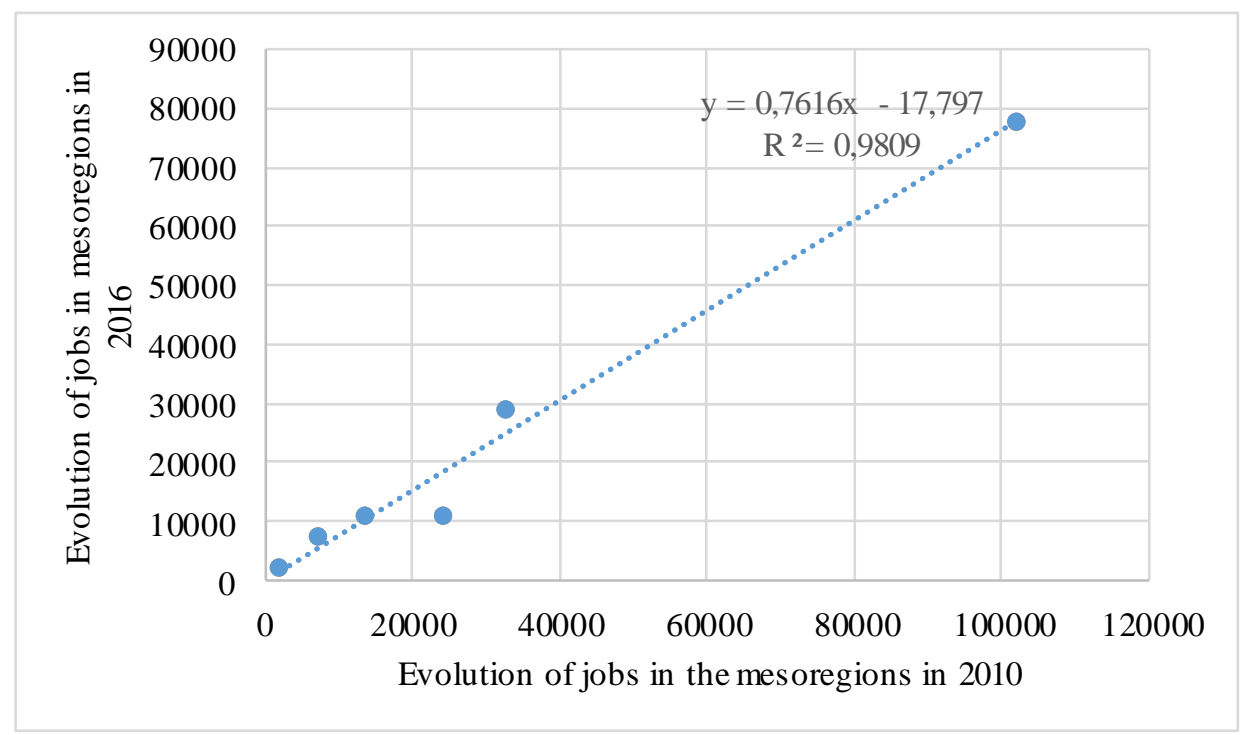

Figure 2. Evolution of jobs generated by mesoregions between 2010 and 2016

Source: Rais, 2010 and 2016. (Data organized by the authors).

Considering the impact of the tax incentive concerning the evolution of the jobs generated between the most incentivized and less incentivized regions this study analyzed the following points: 
The approximate point of 1,000 refers to the southern region of Maranhão that although it was investigated and verified that there are no municipalities considered worse in relation to the HDI, but that some companies in that region were included in the "more companies" program is evident that the south of Maranhão was the region registered a decrease of $-54.18 \%$ compared to 2016 with 2010.

According to Nascimento and Morais $(2009,27 \mathrm{a})$ this reflects the ways in which the economy is structured, with extreme inequality in the distribution of income; in the pattern of employment of the workforce with strong rates of underemployment and informality due to low standards of professional qualification, this lack of specialization is responsible for the low productivity and poor quality of the services produced and it is not because there are no places qualified for teaching- learning, what happens is the inaccessibility of training centers, such as public universities for the majority of the population.

Observing the approximate point of 3,000 (three thousand) in the western region of Maranhão, where the municipality of Imperatriz is located, the second influential in the gross domestic product (GDP), presented a small distance from the linear straight line, which can recurring to the number of unemployed in the region.

In spite of the above, it is summarized that the employment opportunities that were created in each region of Maranhão have been fundamental to maintain the economic development and their relations among themselves, since, according to the statistical data of this study in which it presents $\left(r^{2}\right)=0,9809$ had a strong relation between jobs generated in each region (Dancey and Reidy, 2005).

However, the issue of the HDI makes the state less attractive in the eyes of productive investments because companies do not want to see their "mark" linked to negative aspects and external patterns of sustainable development. (NASCIMENTO and MORAIS, 2009, p, 27b).

Finally, it is concluded that the Maranhense center, despite having a high number of municipalities with a lower HDI, was important in this context, since, given the increase in unemployment, it remained balanced, this reinforces the independence of fiscal incentives.

III. Identification of the main economic activity in relation to the number of jobs generated by meso regions

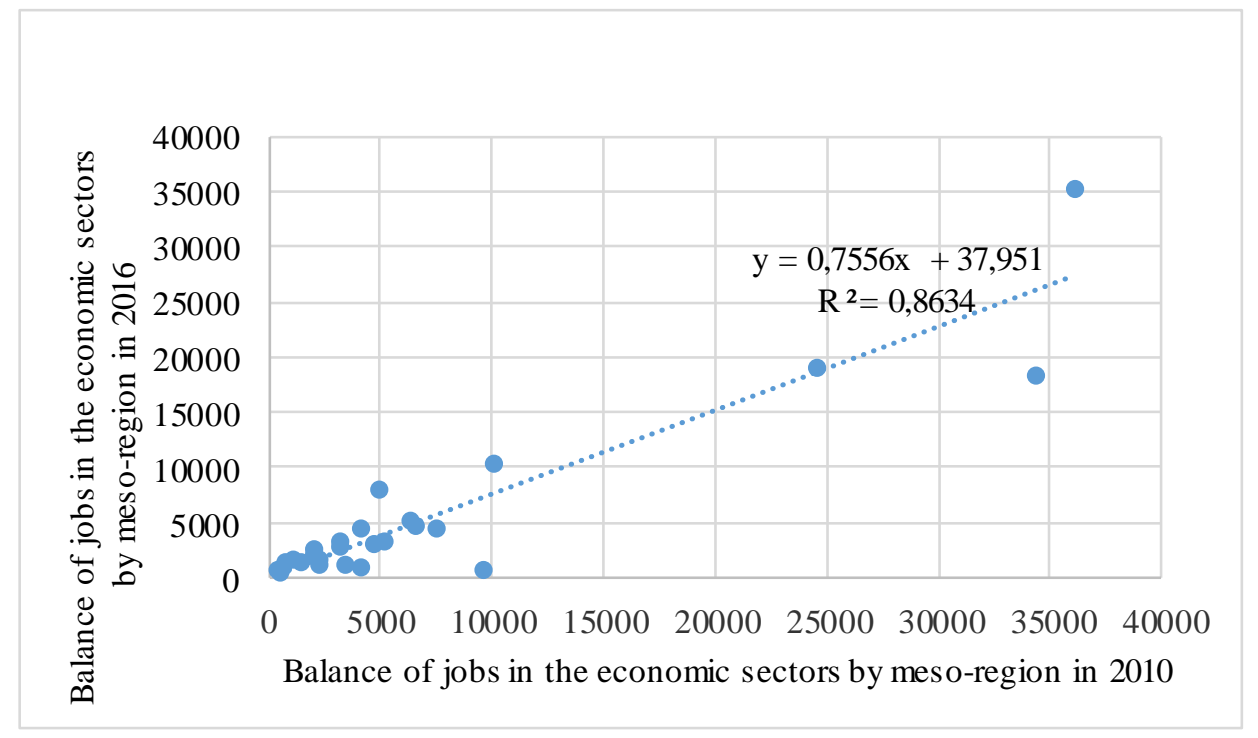

Figure 3. Economic activity sector responsible for employment generation

Source: Rais, 2010 e 2016. (Data organized by the authors).

In the dispersion chart 3 , there is a strong relation between economic sectors such as services, industry, construction, commerce and agriculture, since the linear coefficient is $r^{2}=0.8634$ (DANCEY AND REIDY, 2005). relevance of each sector in the economic context of the state of Maranhão.

Of the five mesoregions analyzed, the South and North Maranhense were the ones that presented the most reduction of generation in all sectors of economic activity, and among the other mesoregion the service sector was the one that 
most impelled the generation of jobs with the exception of the North Maranhense mesoregion that the sector that was more propelling was that of Agropecuária.

In general terms, some sectors presented divergence from the statistical analysis, for example:

- The services sector in the northern region of Maranhão, where, in the approximate amount of 36,000 (thirty-six thousand) jobs generated in the region, there was a negative variation of $-2.19 \%$ in that in 2010 there was 36,103 in the balance of jobs, but in 2016 it was only registered, 35,313.

- The construction sector in the northern region of Maranhão, according to the approximate point of 34,335 in relation to jobs generated by this sector, registered a decrease in the number of jobs, since in 2010 the number of jobs was 34,225 , but in 2016 were only 18,259 jobs and this led to a $46.82 \%$ reduction in the number of jobs in the sector.

- In the South of Maranhão, the civil construction sector suffered a fall in the number of jobs of $93.31 \%$, since in 20109,687 were generated, but in 2016 it was 648 in the sector.

However, when analyzing the sector that most fell in the generation of jobs in the mesoregions like Centro, Leste and Oeste Maranhense, it is noticed that the agricultural sector was the one that was most affected and then, the Civil Construction sector in the mesoregions North and South Maranhense.

\section{Conclusions}

Considering that this study aimed to verify the relationship between the fiscal incentive and the balance of jobs between 2010 and 2016 in Maranhão in the mesoregions, it is concluded that:

- The relationship between fiscal incentives and regions lacking economic development due to the low HDI has been insufficient and therefore it is understood that regions that have municipalities with the worst social indicators will always be ignored by investors, as investors may not be interested to invest in these places, either because of the lack of logistics, or because of the lack of manpower or infrastructure of the cities.

- Although the mesoregions are less encouraged, they are more balanced in relation to jobs, since the non-taxed companies living in those regions have generated employment and income and thus suffer less negative impacts than the more incentivized regions that are the case of the central mesoregion of Maranhão.

Considering also that the problem in this research that was questioning the efficiency of fiscal incentives in relation to the impact on the state's employment equilibrium, the research concluded that the fiscal incentives created between 2006 and 2016 were generally relevant for the Maranhão, but based on statistics, these impacts were small in the poorest regions.

Thus, it is suggested that the government of Maranhão review strategies for granting fiscal incentives, since, if the government gives up receiving part of the taxes with such a concession so that fiscal incentives can generate employment and income in regions with low HDI, this objective could be achieved, otherwise such a concession does not make sense.

Therefore, the hypothesis is confirmed that the idea of the government of Maranhão to create fiscal incentive to stimulate the generation of employment and income, may not impact the regions with low HDI.

\section{References}

Araújo, E.S. (2017). Fiscal incentive programs as inductors of development: the case of Goiás. XVII Enapur, São Paulo. Retrieved May 29, from http://anpur.org.br/xviienanpur/principal/publicacoes/XVII.ENANPUR_Anais/ST_Sessoes_Tematicas/ST\%202 /ST\%202.6/ST\%202.6-03.pdf

Brazil, Law No. 13,089, of January 12, 2015. It establishes the Statute of the Metropolis, amends Law 10,257 of July 10, 2001, and provides other measures

Brazil. (2017). Ministry of Social Development and Fight against Hunger (MDS). Matrix of social information. Retrieved July 4, 2017, from http://aplicacoes.mds.gov.br/sagi/portal/

Brazil. Decree No. 6,047, of February 22, 2007. Establishes the National Policy for Regional Development-PNDR and makes other provisions.

Carvalho, F.C.de. (2015). Regional-territorial development policy and governance: A recent analysis of the state of Maranhão (Brazil). Thesis (doctorate)-Institute of Geosciences and Exact Sciences, Universidade Estadual $\begin{array}{lllll}\text { Paulista. } & \text { Retrieved } & \text { May } & \text { 2017, } & \text { from }\end{array}$ repositorio.unesp.br/bitstream/handle/11449/138539/000864210.pdf?sequence=1 
Cohen, J. (1988). Statistical power analysis for the behavioral sciences. Hillsdale, NJ, Erlbaum.

Dancey, C., \& Reidy, J. (2006). Statistics Without Mathematics for Psychology: Using SPSS for Windows. Porto Alegre, Artmed, 2006.

Felipe, J., Kumar, U., \& Abdon, A. (2010). How Rich Countries Became Rich and Why Poor Countries Remain Poor: It's the Economic Structure ... Duh !. Asian Development Bank, Manila, Philippines. Retrieved May 24, 2017, from http://www.levyinstitute.org/pubs/wp_644.pdf

Figueiredo Filho, D.B., \& Silva Júnior, J.DA. (2009). Unraveling Ministries of Pearson's Correlation Coefficient (r). Revista Política Hoje, 18(1). Retrieved May 20, 2017 from https://www.google.com/url?sa=t\&rct=j\&q=\&esrc=s\&source=web\&cd=1\&ved=0ahUKEwjDz87U55_JAhXMr pAKHRVaBY8QFgggMAA\&url=http\%3A\%2F\%2Fwww.revista.ufpe.br \% 2Fpoliticahoje\% 2Findex.php\% 2Fpolitica\% 2Farticle\% 2FviewFile\% 2F6\% 2F6 \& usg = AFQjCNG1QfVVdplHcuhmm8rYnQMWpVxlvA

Furtado, C. (2005). Economic formation of Brazil (32nd ed.). Companhia Editora Nacional. São Paulo.

Gerhardt, T.E. (2009). The construction of the research. In Gerhardt, T.E. (Org.) \& Silveira, D.T. (Org.), Research Methods. Porto Alegre: Publisher of UFRGS.

Ibge. (2010). Brazilian Institute of Geography and Statistics. Census. Retrieved May 23, 2017, from https://censo2010.ibge.gov.br/

Lynn, L.E. (1980). Designing Public Policy: A Casebook on the Role of Policy Analysis. Santa Monica, Calif. Goodyear.

Maranhão. (2017). Secretary of State for Industry, Commerce and Energy of Maranhão (SEINC/MA). Retrieved May 31, 2017 from http://www.seinc.ma.gov.br/

Maranhão. Law No. 10,259 of June 16, 2015. Establishes the Industrial Development and Economic Integration Program of the State of Maranhão (MAIS EMPRESAS), repeals Law No. 9,121, dated March 4, 2010, and makes other provisions.

Maranhão. Law No. 10,690, dated September 26, 2017. It establishes a system of taxation, in the scope of the Tax on Operations related to the Circulation of Goods and on the Provision of Interstate and Intermunicipal Transportation and Communication Services (ICMS).

Maranhão. Law No. 9,121 of March 4, 2010. Creates the Incentive Program for Industrial and Technological Activities in the State of Maranhão (PROMARANHÃO).

Moore, D.S. (2007). The Basic Practice of Statistics. New York, Freeman.

Nascimento, A.T., \& Morais, M.A.F. (2009). The Maranhão in the rails of the advance? A study of the space-time transformations of Maranhão industry in capitalist society of flexible time. Cad. Pesq., São Luís, 16(3). $\begin{array}{llll}\text { Retrieved December } & 7, & \text { 2017, }\end{array}$ http://www.periodicoseletronicos.ufma.br/index.php/cadernosdepesquisa/article/view/125/92

Oliveira, D.M.de. (2014). Basic sanitation and human development: a case study in the municipality of emperatriz/ma from the training approach. Dissertation (Master). Postgraduate Program in Environment and Development, University Center UNIVATES. Retrieved May 24, 2017, from https://www.univates.br/bdu/bitstream/10737/721/1/2014DiegoMacieldeOliveira.pdf

Ottati, A.M.A., \& Dos A. (2013). The dynamics and the regional developmental problems in the state of Maranhão. Thesis (PhD)-Postgraduate Program in Rural Development of the Faculty of Economic Sciences. Federal University of Rio Grande do Sul. Retrieved May 23, 2017, from https://www.lume.ufrgs.br/bitstream/handle/10183/72257/000883319.pdf?Sequence=1

Peters, B.G. (1986). American public policy. Chatham-NJ: ChathamHouse. https://doi.org/10.1007/978-1-349-18388-3

Reese, L.A. (2005, January). The equity impacts of municipal tax incentives: leveling or tilting the playing field? Annual meeting of the Southern Political Science Association, New Orleans. Retrieved May 23, 2017, from www.mml.org/pdf/tax.pdf

Rodrigues, W., \& Araújo, M.R.N. (2016, Jan/Apr). The policy of granting fiscal benefits in the state of Tocantins: what do institutional actors think ?. Networks (St. Cruz Sul, online), 21(1), 103-120. 
Stanton, J.M.G. (2001). Pearson, and the peas: A brief history of linear regression for statistics instructors. Journal of $\begin{array}{lllllll}\text { Statistical } \quad \text { Education, } & \text { 9, } & \text { Retrieved } & \text { May } & \text { 20, }\end{array}$ http://www.amstat.org/publications/JSE/v9n3/stanton.html

\section{Notes}

Note 1. Municipal Human Development Index

Note 2. The family allowance is a direct transfer program of income for poor individuals ranging between 77.01 and 154 reais (BRAZIL, MDS, 2014).

Note 3. Incentive Program for Industrial and Technological Activities in the state of Maranhão (MARANHÃO, Law No. 9,121 of March 4, 2010).

Note 4. Program of Industrial Development and Economic Integration of the state of Maranhão (MARANHÃO, LAW 10.259 OF JUNE 16, 2015).

Note 5. Over the past two decades, scholars and evaluators have made a number of recommendations for reshaping local economic development policies. No analyst has recommended increasing the use of property tax abatements.

Note 6. Human development Index

Note 7. A Meso-region [...] smaller than that of existing or proposed macro-regions with a common identity, comprising areas of one or more states of the Federation, defined for the purpose of identifying potentialities and vulnerabilities that guide the formulation of socio-economic, cultural, political-institutional and environmental objectives (ARTICLE 3, §5, DECREE No. 6.047, OF FEBRUARY 22, 2007).

Note 8. Para Gerhardt (2009, pp. 81-2), "esta análise [estatística] envolve processamento de dados, através da geração (geralmente usando técnicas de cálculo matemático), apresentação (os dados podem ser organizados em gráficos ou tabelas) e interpretação."

Note 9. Secretary of State for Industry, Commerce and Energy of Maranhão 